\title{
$\angle S$ Research Suare \\ Space Use and Seasonal Movement of Isolated Mountain Goat Populations in the North Cascades, WA
}

Jennifer Sevigny ( $\sim$ jsevigny@stillaguamish.com )

Amanda Summers: Stillaguamish Tribe of Indians, Natural Resources Department, 22712 6th Avenue NE, Arlington, WA 98223 https://orcid.org/0000-0002-1839-3872

Amanda Summers

Stillaguamish Tribe of Indians

Emily George-Wirtz

Sauk-Suiattle Tribe

Research

Keywords: mountain goat, home range, spatial overlap, seasonal range, Cascades

Posted Date: January 13th, 2021

DOl: https://doi.org/10.21203/rs.3.rs-84165/v2

License: (a) (1) This work is licensed under a Creative Commons Attribution 4.0 International License.

Read Full License 


\section{Abstract}

The spatial distribution and seasonal movement patterns of isolated populations of mountain goats (Oreamnos americanus) in the North Cascade range of Washington State is not fully understood. Determining harvest potential in these populations is challenging without a clear understanding of spatiotemporal movement, space use, and spatial overlap. Mountain goat populations in the North Cascades are fragmented and many have declined considerably from historic estimates. Identification of harvestable populations requires a clear understanding of population size, distribution, and movement. We investigated the population trends and spatial distribution of mountain goats in the Boulder River North Harvest Area in the Boulder River Wilderness of Washington State. We reviewed recent mountain goat population estimates and used Global Positioning System collar data to determine year-round and seasonal home range distributions, spatial overlap within these ranges, and proximity of mountain goats to roads and trails. We found 2 populations of mountain goats inhabiting the Whitehorse and Three Fingers Mountains in the Boulder River North Harvest Area. These 2 populations were spatially distinct and did not intermix during our study period. We also found mountain goats using exclusive areas seasonally on Whitehorse Peak. The Whitehorse population appeared to be more vulnerable to harvest than Three Fingers based on its proximity to roads and trails. This study provides space use and movement information on mountain goats in the North Cascades Range that can be used to improve harvest management of fragmented and isolated populations. Our results indicate that a re-evaluation of harvest level, harvest unit boundary, and monitoring strategy may be warranted for the Boulder River North mountain goat harvest area.

\section{Introduction}

The population trends and spatial distribution of mountain goats (Oreamnos americanus) are important considerations for long-term sustainability for populations subject to harvest. Distinct populations can vary substantially in density, habitat use, hunter accessibility, and social interaction (Côtè, 2000; McDonough et al., 2008). Managers consider these factors along with movement and space use patterns when creating mountain goat harvest areas and promoting long-term sustainable harvest of the species. Mountain goat populations in the Cascade Range are a significant cultural resource and provide important subsistence and ceremonial opportunities for Native American tribes (Ballard, 1977; Wigal et al., 1982). Therefore, the long-term persistence of mountain goats on the landscape is essential to protecting tribal treaty rights. Mountain goat populations in the North Cascade Range are currently comanaged by the Washington Department of Fish and Wildlife and the tribes signatory to the Treaty of Point Elliott.

Mountain goats are native to the Cascades (Johnson, 1983; Côtè \& Festa-Bianchet, 2003) and occur in fragmented populations throughout their historic range (Rideout, 1978; Shirk et al., 2010). Overall abundance of mountain goats in Washington State has declined substantially since 1950 (Rice \& Gay, 2010; Rice, 2012) when populations were thought to have exceeded 10,000 (Johnson, 1983). Population declines of mountain goats in Washington have been attributed primarily to historical overharvest (Rice, 
2012). Due to declining populations, a permit only harvest system was established in 1948 and in 1957 permits were allocated according to 10 management areas (Johnson, 1983; Rice \& Gay, 2010). By 1981, those 10 areas were subdivided into 40 smaller areas with subsequent area closures and permit reductions to present day.

Mountain goat populations are believed to be sensitive to overharvest and are slow to recover from population decline (Côtè \& Festa-Bianchet, 2003; Hamel et al., 2006; Festa-Bianchet \& Côtè, 2008). In addition, there appear to be strong effects of population size and group distribution on long-term viability of populations (Côtè \& Festa-Bianchet, 2003). If a harvestable population is composed of small distinct subpopulations, vulnerability may be influenced by the degree of group interactions, migration, home range, and accessibility (Rideout, 1974; Lande et al., 2003). Harvestable populations require a fundamental understanding of population dynamics and spatial structure influences population dynamics (Jonzén et al., 2001). Harvest rate can vary by space and consequently place some populations at greater risk of overexploitation. Terrestrial wildlife management traditionally uses maximum sustainable yield without consideration of spatial distribution on the landscape (Ling \& MilnerGulland, 2008). Spatial dimension could be useful in the management of fragmented populations, specifically where there is an assumed spatially structured metapopulation (McCullough, 1996). Utilization distributions can be used to identify spatiotemporal overlap between human activity and animal movement (Chilvers et al., 2011). Determining harvest potential for sensitive or declining populations of game species requires an understanding of home range and migration patterns.

While some mountain goat populations in Washington State are slowly recovering, others such as those in the Boulder River Wilderness are still declining or remaining static (Rice \& Gay, 2010). The Boulder River North Harvest Area (BRNHA) is located within the Boulder River Wilderness in the Mount Baker Snoqualmie National Forest. The harvest area comprises 2 major mountains, Whitehorse and Three Fingers. The current management strategy infers that these peaks are inhabited by subpopulations of mountain goats (WDFW, 2019). Mountain goat populations that are surveyed annually and meet or exceed population guidelines described in Washington Department of Fish and Wildlife (WDFW, 2014) are considered for recreational hunting (WDFW, 2018). Many of the survey units in the North Cascades are large (Rice et al., 2009) and data from more than 1 subpopulation are often combined to estimate harvest unit totals.

Based on population numbers from aerial surveys (2012-2014), the Washington State Department of Fish and Wildlife initiated a modest harvest in the BRNHA under the assumption that the area met the population requirements of $\geq 100$ animals within a contiguous area (WDFW, 2014). Boulder River North is believed to have a non-kid population of $>100$ goats (Washington Department of Fish and Wildlife unpublished data) with combined counts from the Whitehorse and Three Fingers subpopulations that occur within the harvest area. Even with past research efforts, there are still unknowns about the spatial distribution and consequently harvest potential of mountain goats in this region. In an effort to address this, our objectives were to 1 ) review regional mountain goat population trends, 2) investigate movement and variation in space use patterns to determine population structure, and 3) determine vulnerability of 
mountain goats to harvest and human disturbance within the current BRNHA boundary based on seasonal distributions relative to roads and trails.

\section{Methods}

\section{Study Area}

We studied mountain goats in the federally designated Boulder River Wilderness (199.68 $\mathrm{km}^{2}$ area), within the Mount Baker Snoqualmie National Forest of Washington State. Our focal area was the BRNHA $\left(120.85 \mathrm{~km}^{2}\right)$ with elevation ranges from $200 \mathrm{~m}$ to 2,100 $\mathrm{m}$ above sea level (Figure 1). The BRNHA contained the survey blocks for Whitehorse and Three Fingers mountain goat populations and was characterized by continuous alpine habitat interspersed with drainages, cliffs, alpine lakes, broken terrain, and subalpine forest.

Mountain goats occurred in multiple habitat zones including western hemlock (Tsuga heterophylla), mountain hemlock (Tsuga mertensiana), Pacific silver fir (Abies amabilis), subalpine fir (Abies lasiocarpa), and alpine meadows. The average annual precipitation was 2,064 mm (NOAA, 2020). Alpine plant communities were composed of a mosaic of sedges, grasses, rushes, herbs, forbs, and ericaceous shrubs. Avalanche chutes were common and were distributed throughout the study area bisecting all plant community types.

\section{Data Collection}

Co-managers worked cooperatively to conduct annual helicopter surveys of mountain goats during the months of July and August between 2012 and 2018 in the Boulder River Wilderness. We determined nonkid population estimates $(90 \% \mathrm{Cl})$ using the sightability correction method (Rice et al., 2009). This method was introduced as a binary logistic-regression model that adjusted for visibility bias in wildlife populations (Steinhorst \& Samuel, 1989). Co-managers conducted surveys in 6 units in the Boulder River Wilderness including the Whitehorse and Three Fingers units within the BRNHA (Figure 1). Co-managers estimated the Whitehorse and Three Fingers subpopulations from surveys conducted in the survey blocks shown in Figure 1.

We collared 13 mountain goats in August 2016 via aerial net gunning and chemical immobilization. All capture and handling protocols followed guidelines outlined in Sikes et al. (2016). We targeted female and male mountain goats in the vicinity of Whitehorse and Three Fingers peaks. We applied Global Positioning System (GPS) Globalstar and Iridium tracking collars (SURVEY and VERTEX Lite collars; Vectronic Aerospace, Berlin, Germany) with fix intervals of 12 hours and 85 minutes respectively. We monitored collars between August 2016 and October 2019 and when possible responded to mortality events for necropsies and collar recoveries. Telemetry data obtained from individual mountain goats were 
pooled among years for estimating individual home range and core use areas. Data were also pooled among individuals to determine utilization distributions for each subpopulation.

\section{Data Analyses}

We used the Kernel Density Estimation (KDE) tool of the Spatial Analyst Tool Extension in ArcMap 10.5.1 at the $95 \%$ exceedance value and seasonal $50 \%$ utilization distribution isopleth respectively (Seaman \& Powell, 1996; Kernohan et al., 2001). For comparisons across home range levels, we conducted multiscale assessments of home range values and joint space use for a comprehensive evaluation of distributional differences (Clapp \& Beck, 2015). We calculated the bandwidth $(h)$ based on spatial configuration and the number of input points. We selected our $h$ parameter using the Solve-the-Equation method (Jones et al., 1996; Wand \& Jones, 1994). This approach corrected for spatial outliers and was most appropriate given the size of our dataset (Silverman, 1986; Hemson et al., 2005). We defined seasons based on the median seasons identified in Rice (2008) where the winter season was October $20^{\text {th }}$ to June $5^{\text {th }}$ and the summer season was from June $6^{\text {th }}$ to October $19^{\text {th }}$. This seasonal definition acknowledged the differences in local spatial and temporal variations for individuals by using median dates derived from seasonal altitudinal movements in the Cascade Range of Washington State.

We examined three dimensional home range overlap among collared mountain goats as a means of evaluating joint-space use and degree of interaction among individuals (Kernohan et al., 2001; Millspaugh et al., 2004; Long et al., 2015). We used this method to assess spatial organization in mountain goat populations similar to how others evaluated space use sharing in ungulate species (Fieberg \& Kochanny, 2005; Inselman et al., 2016). We calculated a Utilization Distribution Overlap Index (UDOI) to compare the heterogeneity of use within each mountain goat's home range where overlap occurred and quantified the use of shared space. We calculated UDOI values for $95 \%$ home ranges (total and seasonal) and $50 \%$ seasonal cores as a means of evaluating overlap at 2 spatial scales. This utilization distribution index is similar to the Hurlbert index of niche overlap that assumes subpopulations use space independently of one another (Hurlbert, 1978). Values range from zero (no overlap) to 1 (100\% overlap) and can be $>1$ if both utilization distributions are non-uniformly distributed and have a high degree of overlap.

We calculated density of roads and trails within the $95 \%$ home range areas of the Whitehorse and Three Fingers subpopulations. We measured Euclidean distances of all mountain goat telemetry locations to the nearest road or recreational trail to evaluate the vulnerability of mountain goats within the BRNHA to hunter access and disturbance. We combined primary, secondary, and tertiary roads (both open and closed) along with trails in a single analysis for both populations. We calculated minimum, maximum, and mean Euclidean distances using all fix locations for each collared mountain goat (Rowland et al., 2000). We also calculated frequency of fix distributions by combining all fix locations within the harvest area boundary for each subpopulation by season (summer and winter) in relation to the nearest road or trail. 


\section{Results}

\section{Population Trends}

Based on the 2012-2018 sightability correction estimates, the mean population estimate of mountain goats in the BRNHA was $112 \pm 13$ (Figure 2). The mean population estimates for the Whitehorse and Three Fingers subpopulations were $66 \pm 14$ and $53 \pm 12$, respectively. The individual non-kid population estimates for each subpopulation did not approach or exceed 100 for any year surveyed.

\section{Whitehorse and Three Fingers Subpopulation Distributions}

Of the 13 mountain goats collared, we analyzed location data from 8 animals ( 6 females, 1 adult male, and 1 young male) due to incomplete datasets and relevance to the project focal area. We selected data sets that contained a minimum of 11 months of telemetry location records and occurred within the BRNHA. Estimated ages for collared mountain goats used for analyses ranged from $2-9$ years and the number of location fixes per mountain goat ranged from 572 to 5,931. For the project period, we analyzed a total of 15,354 locations providing robust KDEs. Of the 8 collared mountain goats analyzed, 5 (4 females and 1 adult male) resided on Whitehorse Mountain and 3 ( 2 females and 1 young male) resided on Three Fingers Mountain.

We combined data from collared mountain goats by their respective peaks and calculated $95 \%$ home range areas for the Whitehorse and Three Fingers subpopulations (Figure 3 ). The $95 \%$ home ranges of the Whitehorse and Three Fingers subpopulations were separate and distinct during the project period. The Whitehorse subpopulation resided almost entirely within the BRNHA with $96 \%$ of fixes occurring inside the harvest area boundary. In contrast, only $10 \%$ of the Three Fingers subpopulation occurred inside the area boundary with the greatest utilization distributions occurring outside the harvest area. The Whitehorse $95 \%$ home range area was $9.09 \mathrm{~km}^{2}$ and the Three Fingers $95 \%$ home range area was 5.33 $\mathrm{km}^{2}$ and fix elevations ranged from 200 to $1,928 \mathrm{~m}$ and 558 to $1,841 \mathrm{~m}$ respectively. The Whitehorse and Three Fingers aerial survey units encompassed a portion of the $95 \%$ home ranges with some utilization distribution areas occurring outside the survey units (Figure 3 ). Summer $50 \%$ core areas occurred within the survey blocks for both subpopulations. Collared mountain goats in both the Three Fingers and Whitehorse subpopulations had distinct summer and winter $50 \%$ core areas distributed within the vicinity of their respective peaks.

\section{Whitehorse Spatial Distribution}

We calculated $95 \%$ home ranges for each collared mountain goat in the Whitehorse subpopulation (Figure 4). Home range areas ranged from 3.72 to $14.18 \mathrm{~km}^{2}$ with an elevation range from 200 to $1,928 \mathrm{~m}$ (Table 1). Utilization Distribution Overlap Index values for female mountain goats with intersecting home ranges ranged from 0.03 to 0.93 at the $95 \% \mathrm{KDE}$ isopleth with only 2 instances of overlap $>0.50$ (Table 
2). We examined seasonal spatial distribution at both the $95 \%$ and $50 \%$ isopleth levels (Figure 5). We found the $95 \%$ summer distributions of females 19243, 19245, and 27357 were in close proximity with minimal overlap. The $50 \%$ seasonal core areas for these individuals were spatially separate on the landscape. We calculated UDOI for both $95 \%$ summer and winter ranges and $50 \%$ seasonal core use areas (Table 2). The summer $\mathrm{UDOl}_{95}$ values indicated little to no spatial overlap between collared female mountain goats. Winter $\mathrm{UDOI}_{95}$ values indicated small to moderate levels of overlap between all collared females with 2 animals (19243 and 19246) showing complete overlap (UDOl ${ }_{95}$ winter $\left.=1.03\right)$. We found a decrease in joint space use in the $50 \%$ seasonal core areas and no evidence of range overlap in the summer $50 \%$ cores with the exception of two females $\left(19243\right.$ and 19245, UDOI $\left._{50}=0.02\right)$. Winter core areas produced only $3 \mathrm{UDOI}_{50}$ values $>0$. Seasonal home range size varied by individual with $95 \%$ summer areas ranging from 1.03 to $6.92 \mathrm{~km}^{2}$ and $95 \%$ winter areas ranging from 0.47 to $8.44 \mathrm{~km}^{2}$ (Table 1). Summer core areas ranged from 0.07 to $0.33 \mathrm{~km}^{2}$ and winter core areas ranged from 0.07 to $0.87 \mathrm{~km}^{2}$.

\section{Three Fingers Spatial Distribution}

Unlike the Whitehorse population, mountain goats on Three Fingers had almost complete overlap with no exclusive home range areas at the $95 \% \mathrm{KDE}$ (Figure 6). Home range area (95\%) ranged from 4.43 to 7.46 $\mathrm{km}^{2}$ (Table 1). The young male (19248) had the largest home range area with spatial overlap with both adult females. We found high UDOI values for all $95 \%$ ranges with values $\geq 1$ indicating complete overlap (Table 3). We evaluated seasonal spatial distributions at both the $95 \%$ and $50 \%$ isopleths and found substantial overlap in both the summer and winter $95 \%$ seasonal home ranges (Figure 7). Similar to Whitehorse, the $50 \%$ seasonal core areas had little overlap with the exception of female 27353 and young male 19248. These individuals appeared to be in the same group and maintained overlap $\left(\mathrm{UDOI}_{50}=0.20\right)$ in the seasonal core areas. Seasonal $95 \%$ home range sizes ranged from 1.60 to $4.26 \mathrm{~km}^{2}$ (summer) and 0.78 to $5.50 \mathrm{~km}^{2}$ (winter). Core areas (50\%) ranged from 0.16 to $0.41 \mathrm{~km}^{2}$ (summer) and 0.04 to $0.93 \mathrm{~km}^{2}$ (winter). Indices of home range area did not differ $(P>0.05)$ between summer and winter for both the $\mathrm{HR}_{95}$ and $\mathrm{HR}_{50}$.

\section{Proximity to Roads and Trails}

Trail densities for the $95 \%$ home range areas of Whitehorse and Three Fingers subpopulations were 0.18 $\mathrm{km} / \mathrm{km}^{2}$ and $0.09 \mathrm{~km} / \mathrm{km}^{2}$ respectively. We calculated minimum, maximum and mean Euclidean distance to roads and trails for all collared individuals (Table 4). Collared mountain goats in the Whitehorse subpopulation had smaller minimum distances to roads and trails than collared goats on Three Fingers with the exception of the adult male (19244). We examined the frequency of fix distributions within the harvest area boundary by season for each population and found a higher frequency of fixes closer to roads and trails during the winter season (Figure 8 ). During the winter season, $49 \%$ of Whitehorse subpopulation fixes occurred at $\leq 1,000 \mathrm{~m}$ from roads and trails and during the summer $63 \%$ of fixes 
occurred at $\geq 2,000 \mathrm{~m}$. The Three Fingers subpopulation showed little difference in distance from roads to trails seasonally. Available registry data for trails leading into the Whitehorse and Three Fingers 95\% home range areas indicated more trail use year-round within the Whitehorse subpopulation home range compared to Three Fingers. The 3-year average (2016-2018) for combined Whitehorse trail use was 8,237 users and Three Fingers had an average of 203 users over the same time period (United States Forest Service unpublished data).

\section{Discussion}

This study provides space use and movement information on mountain goats in the North Cascades Range that can be used to improve harvest management of fragmented and isolated populations. Our results suggest that Whitehorse and Three Fingers could be two distinct populations that do not intermix. Whitehorse mountain goats appear to be more vulnerable to human access and disturbance than the Three Fingers population based on spatial distribution and current known trail use and accessibility. Regardless of population size, the distribution and accessibility of each population could increase the vulnerability of overexploitation or extirpation with or without harvest.

Current Washington Department of Fish and Wildlife guidelines limit harvest to $4 \%$ or less in mountain goat populations with $\geq 100$ animals within a contiguous area, with harvest rate reduction occurring if female removal exceeds $1.2 \%$ of the non-kid population during a 3-year period (WDFW 2018). This harvest strategy is based on previous studies that recommend managing mountain goat populations as a collection of smaller subpopulations with distinct female groups and males that may intermix [Rice \& Gay, 2010; Rice 2008). The sustainability of this approach is based on male-only harvest in populations that are $\geq 50$ animals (McDonough \& Selinger, 2008; Hamel et al., 2006; Gonzalez Voyer et al., 2003), but this harvest approach may be detrimental for smaller groups where population recovery is desired.

We found that $96 \%$ of locational fixes for mountain goats on Whitehorse occurred inside the harvest area boundary while only $10 \%$ of fixes for goats on Three Fingers occurred within the harvest area. This variance in habitat use indicates that there could be $<100$ mountain goats in the contiguous area that is considered the BRNHA. The Three Fingers population utilization distribution is primarily outside the harvest area boundary. Given the variation in space use within the BRNHA, the majority of harvest pressure could be on the Whitehorse population, which is $<100$ animals (3-year sightability $\bar{X}=66.33, \sigma=$ 14.01). Similarly, the Three Fingers non-kid population numbers have been consistently $<100$ animals (3year sightability $\bar{X}=53.00, \sigma=12.53$ ) and KDE core use analyses indicate primary distribution during the harvest season (September 1 - December 31) was outside the harvest area.

Our data indicated that the Whitehorse and Three Fingers populations were spatially separate and did not function as a classic metapopulation during our study period. While our sample size was limited, previous studies in the region support the need for understanding mountain goat group interactions in hunted populations (Rice, 2010). We did not examine habitat patch use and habitat suitability within our study area in relation to spatial distribution. However, size and distribution of mountain goat habitat 
characteristics have been documented in Washington State (Wells et al., 2012; Harris et al., 2017). There was no visible explanation for population separation and lack of movement between Whitehorse and Three Fingers Peaks, although there were specific areas void of telemetry locations between the two populations. These areas did not appear to be different in terms of geology, landscape characteristics, or vegetation composition from adjacent areas occupied by collared mountain goats. While it is unclear how social dynamics and group size influence the spatial distributions of mountain goat populations, it is possible that social interactions could have influenced the spatiotemporal movement patterns of collared goats in our study area.

Unlike other ungulates, mountain goats do not preferentially seek out relatives to form subgroups (FestaBianchet \& Côtè, 2008; Festa-Bianchet, 1991). Adult female mountain goats maintain a stable and linear hierarchy and are often aggressive to each other during encounters (Côtè, 2000; Fournier \& FestaBianchet, 1995). Avoidance behavior may keep adjacent populations from mixing and social organization can change rapidly over space and time (Festa-Bianchet \& Côtè, 2008). Furthermore, adult females typically display fidelity to their summer home ranges areas (Fox et al., 1989; Houston et al., 1994). We observed spatial separation with the adult male and levels of separation between collared females seasonally. Small mountain goat populations in rugged terrain may have more solitary individuals due to a reduced need for antipredator protection (Festa-Bianchet \& Côtè, 2008). These small populations could be subject to overharvest and eventual extirpation.

In addition to harvest limits, hunter accessibility to small populations of mountain goats can increase the vulnerability of extirpation. In the BRNHA, the Whitehorse population appears to be more vulnerable to harvest than the Three Fingers population due to accessibility and the spatial distribution of goats in the Whitehorse home range areas. Collared mountain goats on Whitehorse had more locational data close to roads and trails and $96 \%$ of location fixes occurred inside the harvest area. State harvest data indicate that mountain goats are being harvested in the vicinity of trails primarily from the Whitehorse population (Washington Department of Fish and Wildlife unpublished data).

\section{Management Implications}

Given our study's support for the existence of two mountain goat populations in the BRNHA, the size, distribution, and movement of each population should be considered in harvest management. Although the apparent stability in population estimates and combined population totals may justify allowing a limited harvest in Boulder River North, we recommend a harvest strategy that addresses management of the Whitehorse and Three Fingers mountain goats as separate populations. Our results suggest that the current mountain goat harvest strategy should restrict harvest in the BRNHA until there are $\geq 100$ mountain goats in each of the Whitehorse and Three Fingers populations. Because mountain goats in the Cascades Range are co-managed between the state and Native American tribes, harvest strategies should promote population growth and sustainability to provide equal harvest opportunity for all hunters. 
If harvest eligibility of a population is based on a minimum of 100 animals within a contiguous area, there is a need to clearly define what constitutes a contiguous area and how that area is identified on the landscape in relation to mountain goat space use and movement. Regardless of geographic connectivity within a contiguous area, the social dynamics of mountain goats may inhibit the likelihood of a metapopulation structure within the greater area. Our study suggests that for harvest to continue in the BRNHA, the harvest area boundary should be adjusted to incorporate a wider distribution of mountain goats to minimize overharvest of a single population. Managers can only control hunter distribution by setting precise geographic boundaries that are appropriate for known spatial distributions of mountain goats (Bailey 1986). A redefined harvest area could also balance accessibility and harvest pressure on the Whitehorse population and provide added refuge habitat. This would be consistent with the state's position that harvest areas should have dispersed hunter access to prevent overharvest of smaller groups.

We recommend annual population surveys until population estimates are $>100$ and demonstrating continual growth with additional consideration of raw counts associated with collared individuals as a means of monitoring subpopulations within the Whitehorse and Three Fingers range areas. We also recommend revising the sightability correction model to provide a $95 \%$ confidence interval on estimates. We agree with the set mitigation for restricting harvest for at least one year if a female is harvested and support the mandatory carcass inspection instituted in 2015. We suggest an annual evaluation of acceptable harvest, vital rates, population size, and harvest location. Further investigation into the role of social dynamics and understanding other vulnerability risks will also be important for ensuring the persistence of mountain goats on the landscape.

Mountain goats are likely to be impacted by current and future climatic changes and understanding which populations are under the most climate-related stress will be important in coming years (Epps et al., 2004). In regions of Alaska, it is predicted that climate change will lead to the extinction of the majority of mountain goat populations before 2085 (White et al., 2017). Warmer temperatures during the last 30 years have affected the function and composition of ecological communities and the phenology and distribution of many species (Jonzén et al., 2001). Mountain goats lack the flexibility of other large mammals to adapt to rising temperatures and a dependence on snowy habitat puts their populations at risk (Sarmento et al., 2019). Furthermore, little is known about how a changing climate might affect the social dynamics of mountain goat populations, especially those with limited immigration and emigration. Monitoring habitat fragmentation, food availability and predator detection capability along with restoring population connectivity will be necessary to ensure long-term genetic sustainability and buffer the effects of climate change (Epps et al., 2006). Restoring populations in vacant historic habitat and augmenting existing populations such as Whitehorse and Three Fingers could prevent extirpation or decline and increase harvest potential in the future.

\section{Declarations}




\section{Acknowledgements}

This study was a cooperative effort between the Stillaguamish Tribe of Indians, Sauk-Suiattle Indian Tribe, and Tulalip Tribes. We would like to thank the United States Forest Service for assistance in permitting and manuscript review. We thank the Washington Department of Fish and Wildlife and other tribal co-managers for monitoring and population data. Support for this project was provided by the Stillaguamish, Sauk-Suiattle and Tulalip Tribes along with the Department of Interior/United States Fish and Wildlife Service via a Tribal Wildlife Grant (CFDA 15.639; F16AS00050).

\section{Author's Contributions}

All authors were involved in the research concept, study design, and funding acquisition. EGW obtained permits and worked on the safe capture plan. All authors were involved in data collection and field operations. JS and AS wrote the manuscript and all authors discussed results and made final edits to the manuscript.

\section{Availability of Data and Materials}

The datasets used and/or analyzed for this study are available from the corresponding author on reasonable request.

\section{Competing Interests}

The authors declare that they have no competing interests.

\section{References}

Bailey, J.A. (1986) Harvesting mountain goats: strategies, assumptions, and needs for management and research. Proceedings of the Northern Wild Sheep and Goat Council, 5, 37-47.

Ballard, W. (1977) 'Status and management of the mountain goat in Alaska' in Samuel, W., \& Macgregor, W.G. (eds.) Proceedings of the first international mountain goat symposium. Kalispell, Montana, 1, 1523.

Chilvers, L.B., Amey, J.M., Huckstadt, L.A., \& Costa, D.P. (2011) Investigating foraging utilization distribution of female New Zealand sea lions, Auckland Islands. Polar Biology, 34, 565-574.

Clapp, J.G., \& Beck, J.L. (2015) Evaluating distributional shifts in home range estimates. Ecology and Evolution, 5(18), 3869-3878. 
Côtè, S.D. (2000) Dominance hierarchies in female mountain goats: stability, aggressiveness and determinants of rank. Behaviour, 137(11), 1541-1566.

Côtè, S.D., \& Festa-Bianchet, M. (2003) 'Mountain goat' in Feldhamer, G.A., Thompson, B., \& Chapman, J. (eds.) Wild mammals of North America: biology, management, and conservation. Second edition. Baltimore: Johns Hopkins University Press, pp. 1061-1075.

Epps, C.W., McCullough, D.R., Wehausen, J.D., Bleich, V.C., \& Rechel, J.L. (2004) Effects of climate change on population persistence of desert-dwelling mountain sheep in California. Conservation Biology, 18(1), 102-113.

Epps, C.W., Palsboll, P.J., Wehausen, J.D., McCullough, D.R. (2006) Elevation and connectivity define genetic refugia for mountain sheep as climate warms. Molecular Ecology, 15(14), 4295-4302.

Festa-Bianchet, M. (1991) The social system of bighorn sheep: grouping patterns, kinship and female dominance rank. Animal Behavior, 42(1), 71-82.

Festa-Bianchet, M., \& Côtè, S.D. (2008) Mountain Goats: ecology, behavior, and conservation of an alpine ungulate. $1^{\text {st }}$ edn. Washington, D.C.: Island Press.

Fieberg, J., \& Kochanny, C. O. (2005) Research and management viewpoint - quantifying home-range overlap: the importance of the utilization distribution. Journal of Wildlife Management, 69(4), 1346-1359.

Fournier, F., \& Festa-Bianchet, M. (1995) Social dominance in adult female mountain goats. Animal Behavior, 49(6), 1449-1459.

Fox, J.L., Smith, C.A., \& Schoen, J.W. (1989) Relation between mountain goats and their habitat in southeastern Alaska. General Technical Report PNW-GTR-246. U.S. Forest Service, Pacific Northwest Research Station, Portland, OR.

Gonzalez Voyer, A., Smith, K.G., \& Festa-Bianchet, M. 2003. Dynamics of hunted and unhunted mountain goat Oreamnos americanus populations. Wildlife Biology, 9(3), 213-218.

Hamel, S., Côtè, S.D., Smith, K.G., \& Festa-Bianchet, M. (2006) Population dynamics and harvest potential of mountain goat herds in Alberta. Journal of Wildlife Management, 70, 1044-1053.

Harris, R.B., Rice, C.G., Wells, A.G. (2017) Influence of geological substrate on mountain goat forage plants in the North Cascades, Washington State. Northwest Science, 91(3), 301-313.

Hemson, G., Johnson, P., South, A., Kenward, R., Ripley, R., \& MacDonald, D. (2005) Are kernels the mustard? Data from global positioning system (GPS) collars suggests problems for kernel home-range analyses with least-squares cross-validation. Journal of Animal Ecology, 74, 455-463. 
Houston, D.B., Schreiner, E.G., \& Moorhead, B.B. (1994) Mountain goats in Olympic National Park: biology and management of an introduced species. Scientific Monograph NPS/NROLYM/NRSM-94/25, National Park Service, Port Angeles, WA, p.244.

Hurlbert, S.H. (1978) The measurement of niche overlap and some relatives. Ecology, 59(1), 67-77.

Inselman, W.M., Datta, S., Jenks, J.A., Klaver, R.W., \& Grovenburg, T.W. (2016) Spatial ecology and survival of Swainson's Hawks (Buteo swainsoni) in the northern Great Plains. Journal of Raptor Research, 50(4), 338-350.

Johnson, R.L. (1983) Mountain goats and mountain sheep of Washington. Washington State Game Department Biological Bulletin 18, Olympia, WA, p. 206.

Jones, M.C., Marron, J.S., \& Sheather, S.J. (1996) A brief survey of bandwidth selection for density estimation. Journal of the American Statistical Association, 91(433): 401-407.

Jonzén, N., Lundberg, P., \& Gårdmark, A. (2001) Harvesting spatially distributed populations. Wildlife Biology, 7(3), 197-203.

Kernohan, B.J., Gitzen, R.A., \& Millspaugh, J.J. (2001) 'Analysis of animal space use and movements' in Marzluff, J.M. (ed.) Radio Tracking and Animal Populations. San Diego: Academic Press, pp. 125-166.

Lande, R., Engen, S., \& Sæther, B.E. 2003. Stochastic population dynamics in ecology and conservation. New York: Oxford University.

Ling, S., \& Milner-Gulland, E.J. (2008) When does spatial structure matter in models of wildlife harvesting? Journal of Applied Ecology, 45, 63-71.

Long, J.A., Webb, S.L., Nelson, T.A., \& Gee, K.L. (2015) Mapping areas of spatial-temporal overlap from wildlife tracking data. Movement Ecology, 3(38), 38-61.

McDonough, T.J., \& Selinger, J.S. (2008) Mountain goat management on the Kenai Peninsula, Alaska: a new direction. Biennial Symposium of the Northern Wild Sheep and Goat Council, 16, 50-67.

McCullough, D.R. (1996) Spatially structured populations and harvest theory. Journal of Wildlife Management, 60(1), 1-9.

Millspaugh, J.J., Brundige, G.C., Gitzen, R.A., \& Raedeke, K.J. (2004) Herd organization of cow elk in Custer State Park, South Dakota. Wildlife Society Bulletin, 32(2), 506-514.

NOAA (National Oceanic and Atmospheric Administration). (2020) Climate Data Online. Available at: https://www.ncdc.noaa.gov/cdo-web/ (Accessed 7 January 2021)

Rice, C.G. (2008) Seasonal altitudinal movements of mountain goats. Journal of Wildlife Management 72(8), 1706-1716. 
Rice, C.G. (2012) Status of mountain goats in Washington. Biennial Symposium of the Northern Wild Sheep and Goat Council, 18, 64-70.

Rice, C.G., Jenkins, K.J., \& Chang, W. (2009) A sightability model for mountain goats. Journal of Wildlife Management, 73(3), 468-478.

Rice, C.G., \& Gay, D. (2010) Effects of mountain goat harvest on historic and contemporary populations. Northwest Naturalist, 91, 40-57.

Rideout, C.B. (1974) A radio telemetry study of the ecology and behavior of the mountain goat in western Montana. Dissertation, University of Kansas, Lawrence, KS. p. 146.

Rideout, C.B. (1978) 'Mountain goat' in Schmidt, J.L.D., \& Gilbert, D.L. (eds.) Big game of North America: ecology and management. Harrisburg: Stackpole Books, pp. 149-159.

Rowland, M.M., Wisdom, M.J., Johnson, B.K., \& Kien, J.G. (2000) Elk distribution and modeling in relation to roads. Journal of Wildlife Management, 64(3):672-684.

Sarmento, W., Biel, M., \& Berger, J. (2019) Seeking snow and breathing hard - behavioral tactics in high elevation mammals to combat warming temperatures. PLOS ONE, 14(12):e0225456.

Seaman, D.E., \& Powell, R.A. (1996) An evaluation of the accuracy of kernel density estimators for home range analyses. Ecology, 77, 2075-2085.

Shirk, A.J., Wallin, D.O., Cushman, S.A., Rice, C.G., \& Warheit, K.I. (2010) Inferring landscape effects on gene flow: a new model selection framework. Molecular Ecology, 19, 3603-3619.

Sikes R.S., \& The Animal Care and Use Committee of the American Society of Mammalogists. (2016) Guidelines of the American Society of Mammalogists for the use of wild mammals in research and education. Journal of Mammalogy, 97, 663-688.

Silverman, B.W. (1986) Density estimation for statistics and data analysis. Monographs on Statistics and Applied Probability. London: School of Mathematics University of Bath.

Steinhorst, K.R., \& Samuel, M.D. (1989) Sightability adjustment methods for aerial surveys of wildlife populations. Biometrics, 45, 415-425.

Wand, M.P., \& Jones, M.C. (1994) Kernel Smoothing. $1^{\text {st }}$ edn. New York: Chapman and Hall

WDFW (Washington Department of Fish and Wildlife). (2014) 2015-2021 Game management plan. Wildlife Program, Washington Department of Fish and Wildlife, Olympia, WA. p. 165.

WDFW (Washington Department of Fish and Wildlife). (2018) Game status and trend report, Washington Department of Fish and Wildlife, Olympia, WA. p. 398. 
WDFW (Washington Department of Fish and Wildlife). (2019) Washington big game: 2019 hunting seasons and regulations, Washington Department of Fish and Wildlife, Olympia, WA. p. 137.

Wells, A.G., Rachlow, J.L., Garton, E.O., \& Rice, C.G. (2012) Mapping vegetation communities across home ranges of mountain goats in the North Cascades for conservation and management. Applied Vegetation Science, $15,560-570$.

White, K.S., Gregovich, D.P., \& Levi, T. (2017) Projecting the future of an alpine ungulate under climate change scenarios. Global Change Biology, 24, 1136-1149.

Wigal, R.A. \& Coggins, V.L. (1982) 'Mountain goat' in: Chapman, J.A. \& Feldhamer, G.A. (eds.) Wild mammals of North America: biology, management, and economics. Baltimore: Johns Hopkins University Press, pp. 1008-20.

\section{Tables}

Table 1 Individual mountain goat home range (95\%) areas, seasonal core (50\%) areas, and elevation ranges within the Whitehorse and Three Fingers subpopulations in the Boulder River Wilderness, Washington State, USA (August 2016-October 2019).

\begin{tabular}{|c|c|c|c|c|c|c|c|c|}
\hline $\begin{array}{l}\text { Animal } \\
\text { ID }\end{array}$ & Population & $\begin{array}{l}\text { Sex/life } \\
\text { Stage } \\
\text { (years) }\end{array}$ & $\begin{array}{l}95 \% \\
\text { Home } \\
\text { range } \\
\text { area } \\
\left(\mathrm{km}^{2}\right)\end{array}$ & $\begin{array}{l}95 \% \\
\text { Summer } \\
\text { range } \\
\text { area } \\
\left(\mathrm{km}^{2}\right)\end{array}$ & $\begin{array}{l}95 \% \\
\text { Winter } \\
\text { range } \\
\text { area } \\
\left(\mathrm{km}^{2}\right)\end{array}$ & $\begin{array}{l}50 \% \\
\text { Summer } \\
\text { core } \\
\text { area } \\
\left(\mathrm{km}^{2}\right)\end{array}$ & $\begin{array}{l}50 \% \\
\text { Winter } \\
\text { core } \\
\text { area } \\
\left(\mathrm{km}^{2}\right)\end{array}$ & $\begin{array}{l}\text { Elevation } \\
\text { range } \\
(\mathrm{m})\end{array}$ \\
\hline 19243 & Whitehorse & $\begin{array}{l}\text { Female/3- } \\
4\end{array}$ & 10.16 & 3.22 & 6.67 & 0.30 & 0.87 & $\begin{array}{l}354- \\
1844\end{array}$ \\
\hline 19244 & Whitehorse & Male/7 & 1.36 & 1.03 & 0.47 & 0.07 & 0.07 & $\begin{array}{l}734- \\
1850\end{array}$ \\
\hline 19245 & Whitehorse & Female/4 & 10.54 & 6.92 & 1.14 & 0.33 & 0.06 & $\begin{array}{l}489- \\
1928\end{array}$ \\
\hline 19246 & Whitehorse & Female/6 & 14.18 & 2.45 & 8.44 & 0.17 & 0.82 & $\begin{array}{l}570- \\
1887\end{array}$ \\
\hline 27357 & Whitehorse & Female/6 & 3.72 & 2.60 & 3.06 & 0.16 & 0.31 & $\begin{array}{l}200- \\
1861\end{array}$ \\
\hline 19247 & $\begin{array}{l}\text { Three } \\
\text { Fingers }\end{array}$ & $\begin{array}{l}\text { Female/4- } \\
5\end{array}$ & 4.43 & 1.60 & 0.78 & 0.16 & 0.04 & $\begin{array}{l}730- \\
1692\end{array}$ \\
\hline 19248 & $\begin{array}{l}\text { Three } \\
\text { Fingers }\end{array}$ & Male/2-3 & 7.46 & 4.26 & 5.50 & 0.26 & 0.93 & $\begin{array}{l}688- \\
1723\end{array}$ \\
\hline 27353 & $\begin{array}{l}\text { Three } \\
\text { Fingers }\end{array}$ & Female/9 & 4.93 & 3.11 & 1.54 & 0.41 & 0.07 & $\begin{array}{l}616- \\
1841\end{array}$ \\
\hline
\end{tabular}


Table 2 Home range overlap calculated using the Utilization Distribution Overlap Index (UDOI) for collared mountain goats in the Whitehorse subpopulation in the Boulder River Wilderness, Washington State, USA (August 2016-October 2019).

\begin{tabular}{|llllll|}
\hline Animal ID & UDOI $_{95}$ & UDOI $_{95}$ Summer & UDOI $_{95}$ Winter & UDOI $_{50}$ & UDOI $_{50}$ \\
& & & & Summer & Winter \\
\hline $19243-19244$ & 0 & 0 & 0 & 0 & 0 \\
\hline $19243-19245$ & 0.47 & 0.09 & 0.24 & 0.02 & 0.27 \\
\hline $19243-19246$ & 0.68 & 0.02 & 1.03 & 0 & 0.02 \\
\hline $19243-27357$ & 0.04 & 0 & 0.16 & 0 & 0 \\
\hline $19244-19245$ & 0 & 0 & 0 & 0 & 0 \\
\hline $19244-19246$ & 0 & 0 & 0 & 0 & 0 \\
\hline $19244-27357$ & 0 & 0 & 0 & 0 & 0 \\
\hline $19245-19246$ & 0.93 & 0.43 & 0.31 & 0 & 0.04 \\
\hline $19245-27357$ & 0.04 & 0.01 & 0.06 & 0 & 0 \\
\hline $19246-27357$ & 0.03 & 0.01 & 0.15 & 0 & 0 \\
\hline
\end{tabular}

Table 3 Home range overlap calculated using the Utilization Distribution Overlap Index (UDOI) for collared mountain goats in the Three Fingers subpopulation in the Boulder River Wilderness, Washington State, USA (August 2016-October 2019).

\begin{tabular}{|llllll|}
\hline Animal ID & UDOI $_{95}$ & UDOI $_{95}$ Summer & UDOI $_{95}$ Winter & UDOI $_{50}$ & UDOI $_{50}$ \\
Summer & Winter \\
\hline $19247-19248$ & 0.71 & 0.47 & 0.28 & 0.01 & 0.03 \\
\hline $19247-27353$ & 1.01 & 0.64 & 0.35 & 0.01 & 0 \\
\hline $19248-27353$ & 1.07 & 0.63 & 0.34 & 0.20 & 0.20 \\
\hline
\end{tabular}


Table 4 Distance to roads and trails (combined) from locational fixes of collared mountain goats in the Whitehorse and Three Fingers subpopulations in the Boulder River Wilderness, Washington State, USA (August 2016-October 2019).

\begin{tabular}{|llllll|}
\hline Subpopulation & $\begin{array}{l}\text { Animal } \\
\text { ID }\end{array}$ & $\begin{array}{l}\text { Minimum Distance } \\
(\mathrm{m})\end{array}$ & $\begin{array}{l}\text { Maximum Distance } \\
(\mathrm{m})\end{array}$ & $\begin{array}{l}\bar{X} \\
(\mathrm{~m})\end{array}$ & Distance \\
\hline Whitehorse & 19243 & 0.23 & $3,594.60$ & $1,967.30$ & 31.29 \\
\hline Whitehorse & 19244 & 473.27 & $3,316.39$ & $2,167.30$ & 21.16 \\
\hline Whitehorse & 19245 & 0.04 & $3,493.07$ & $1,016.52$ & 28.20 \\
\hline Whitehorse & 19246 & 0.01 & $3,535.95$ & $1,827.91$ & 39.60 \\
\hline Whitehorse & 27357 & 11.23 & $3,567.67$ & $1,338.56$ & 8.84 \\
\hline Three Fingers & 19247 & 119.77 & $2,249.32$ & $1,045.54$ & 25.82 \\
\hline Three Fingers & 19248 & 22.65 & $2,493.34$ & $1,298.65$ & 15.21 \\
\hline Three Fingers & 27353 & 49.78 & $2,248.02$ & 978.06 & 12.89 \\
\hline
\end{tabular}

\section{Figures}




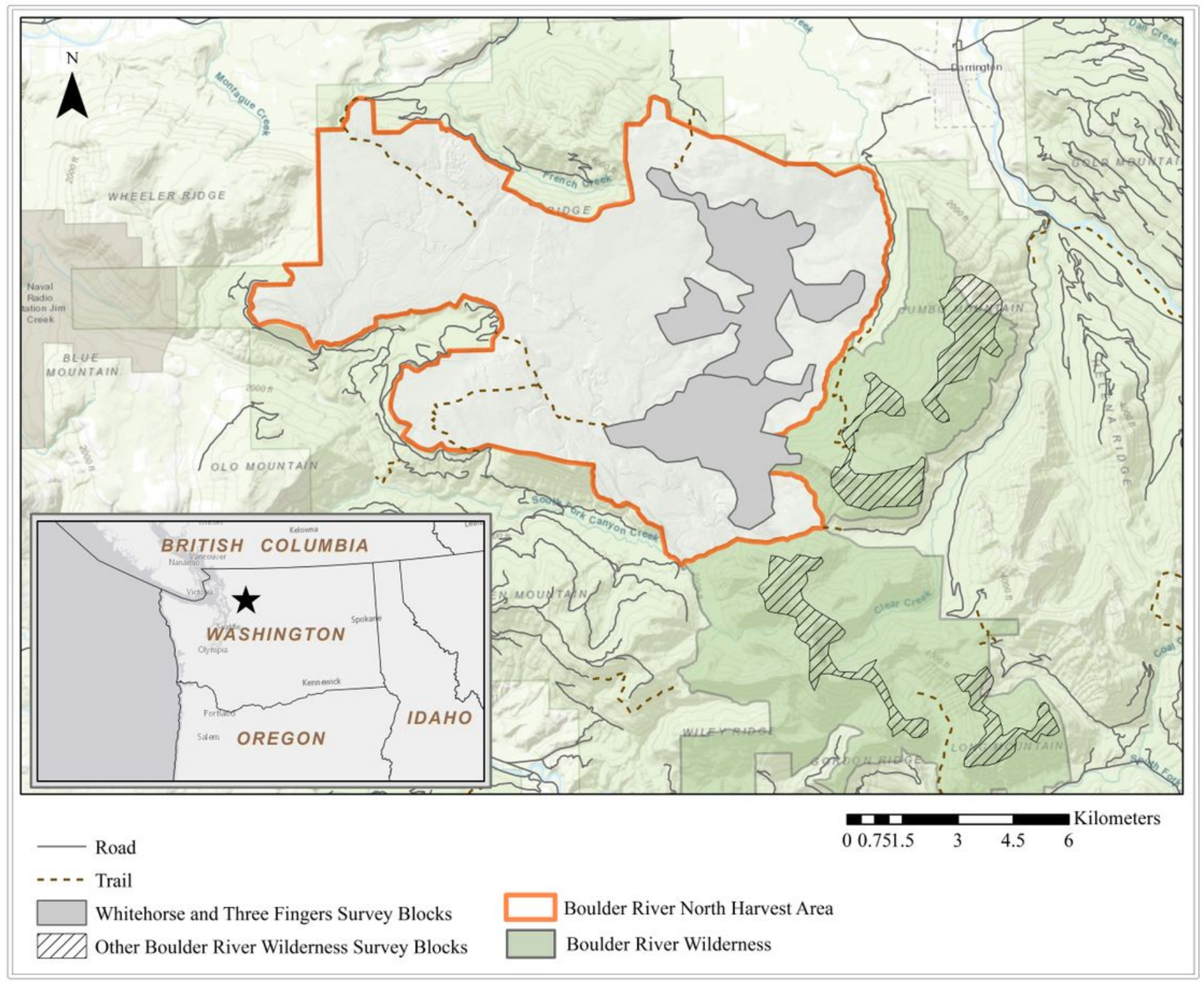

Figure 1

Mountain goat study area including the Boulder River North Harvest Area, mountain goat aerial survey blocks, roads, and trails, within the Boulder River Wilderness, Washington State, USA. Note: The designations employed and the presentation of the material on this map do not imply the expression of any opinion whatsoever on the part of Research Square concerning the legal status of any country, territory, city or area or of its authorities, or concerning the delimitation of its frontiers or boundaries. This map has been provided by the authors. 


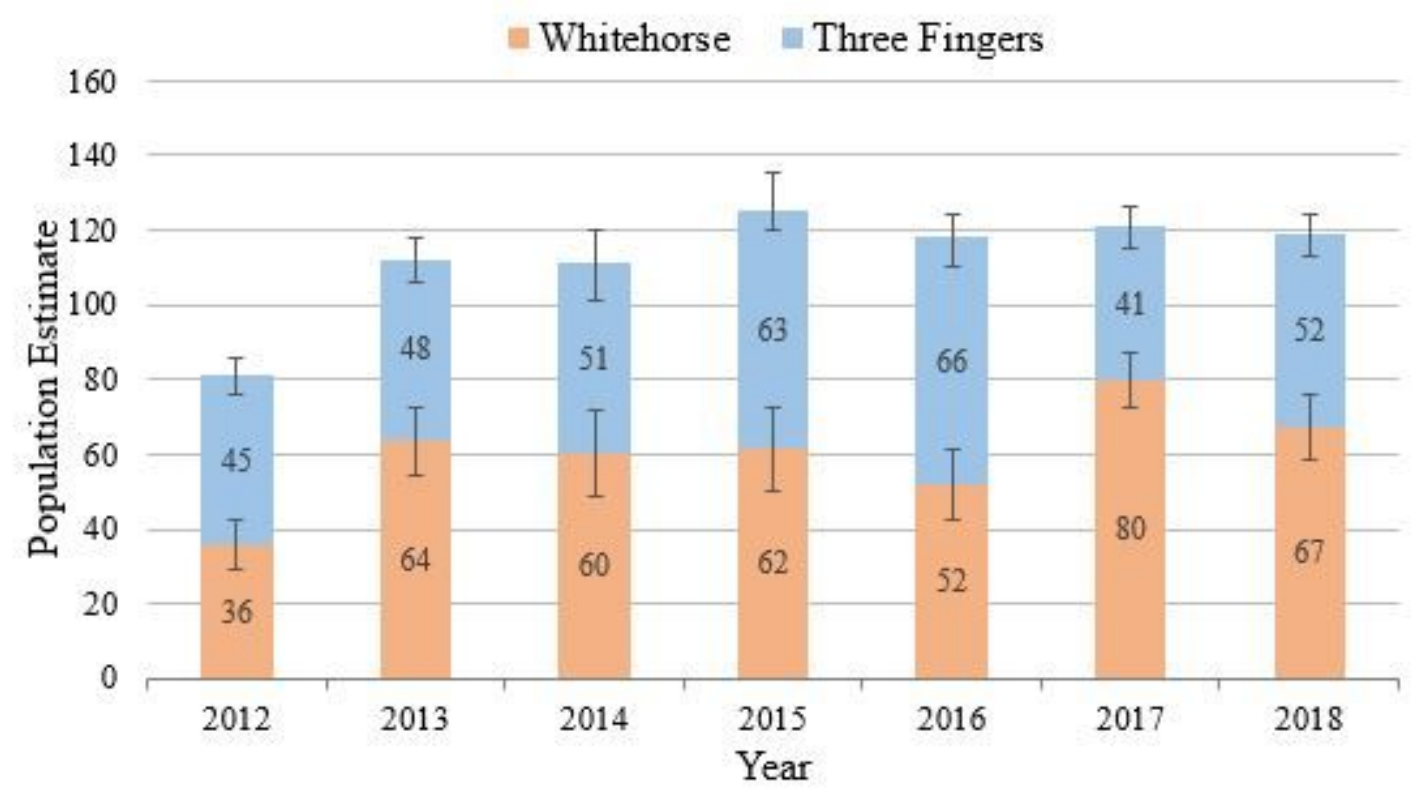

\section{Figure 2}

Sightability correction mountain goat population estimates $(90 \% \mathrm{Cl})$ for the non-kid population (adult + yearling) by year for the Whitehorse and Three Fingers subpopulations in the Boulder River Wilderness, Washington State, USA. 


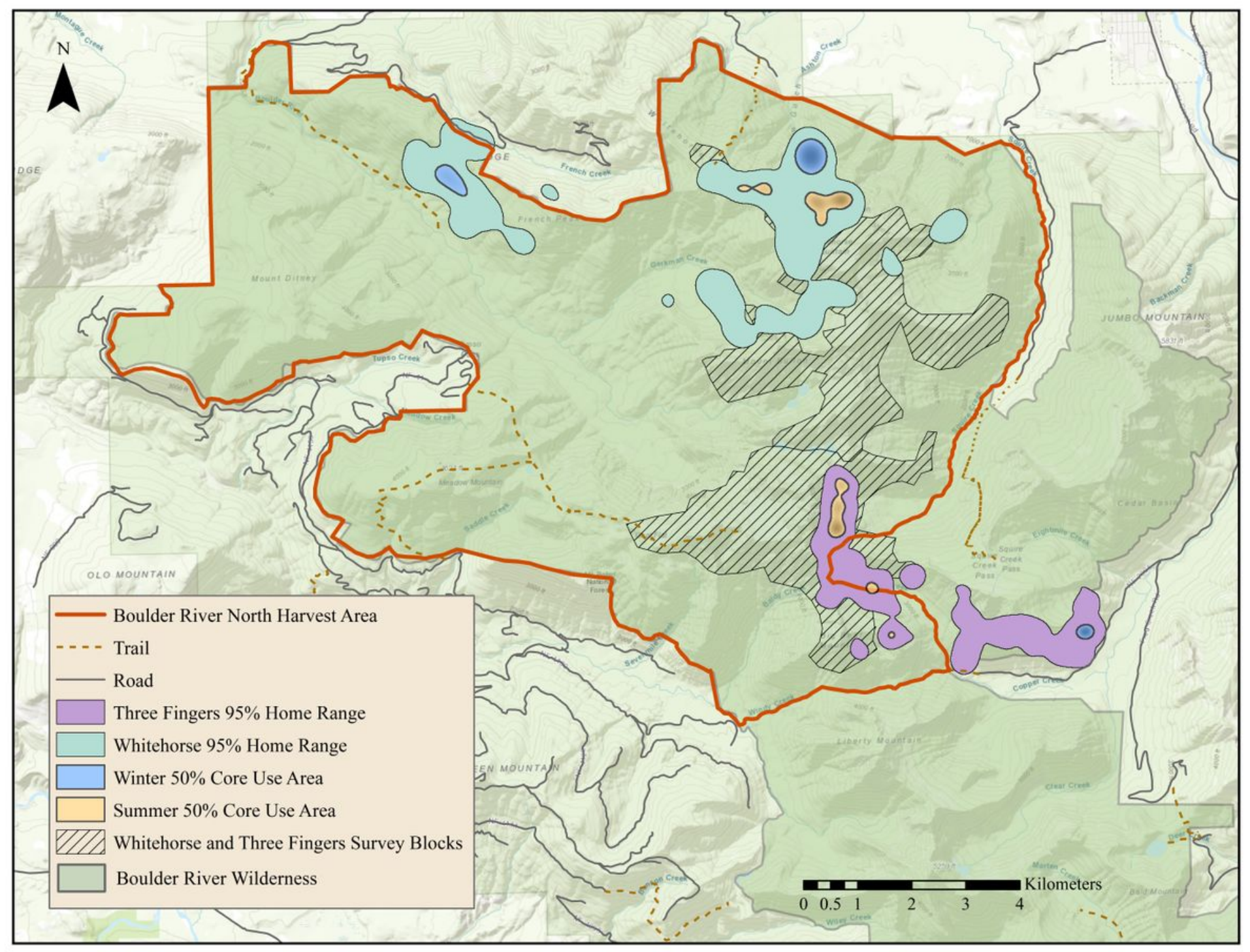

Figure 3

Home range (95\%) distribution with summer and winter seasonal cores (50\%) for the Whitehorse and Three Fingers mountain goat populations in the Boulder River North Harvest Area. Home range polygons overlay the aerial survey blocks for Whitehorse and Three Fingers Peaks in the Boulder River Wilderness in Washington State, USA (August 2016-October 2019). Note: The designations employed and the presentation of the material on this map do not imply the expression of any opinion whatsoever on the part of Research Square concerning the legal status of any country, territory, city or area or of its authorities, or concerning the delimitation of its frontiers or boundaries. This map has been provided by the authors. 


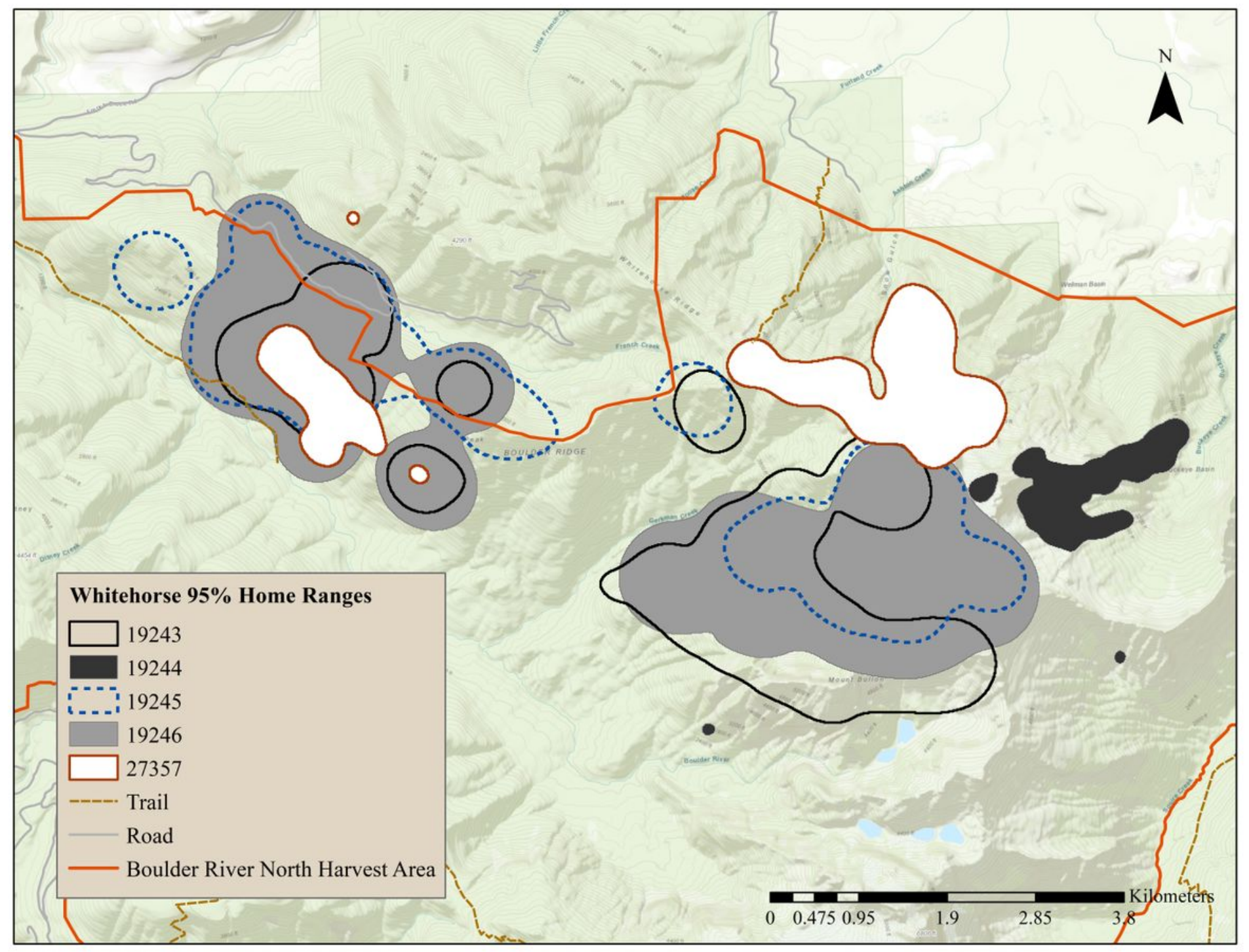

Figure 4

Home range (95\%) distributions for individual mountain goats on Whitehorse Mountain in the Boulder River Wilderness, Washington State, USA (August 2016-October 2019). Note: The designations employed and the presentation of the material on this map do not imply the expression of any opinion whatsoever on the part of Research Square concerning the legal status of any country, territory, city or area or of its authorities, or concerning the delimitation of its frontiers or boundaries. This map has been provided by the authors. 


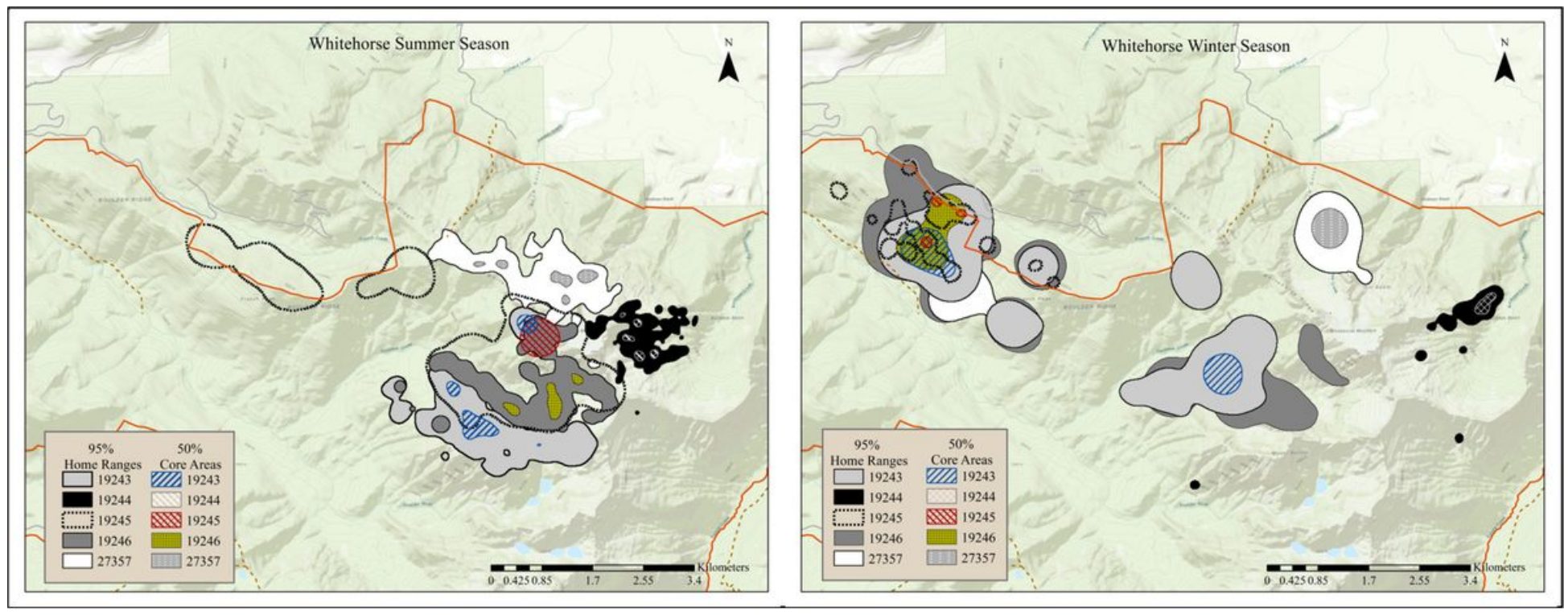

\section{Figure 5}

Seasonal home Range (95\%) and core use (50\%) areas for individual mountain goats on Whitehorse Mountain in the Boulder River Wilderness, Washington State, USA (August 2016-October 2019). Note: The designations employed and the presentation of the material on this map do not imply the expression of any opinion whatsoever on the part of Research Square concerning the legal status of any country, territory, city or area or of its authorities, or concerning the delimitation of its frontiers or boundaries. This map has been provided by the authors. 


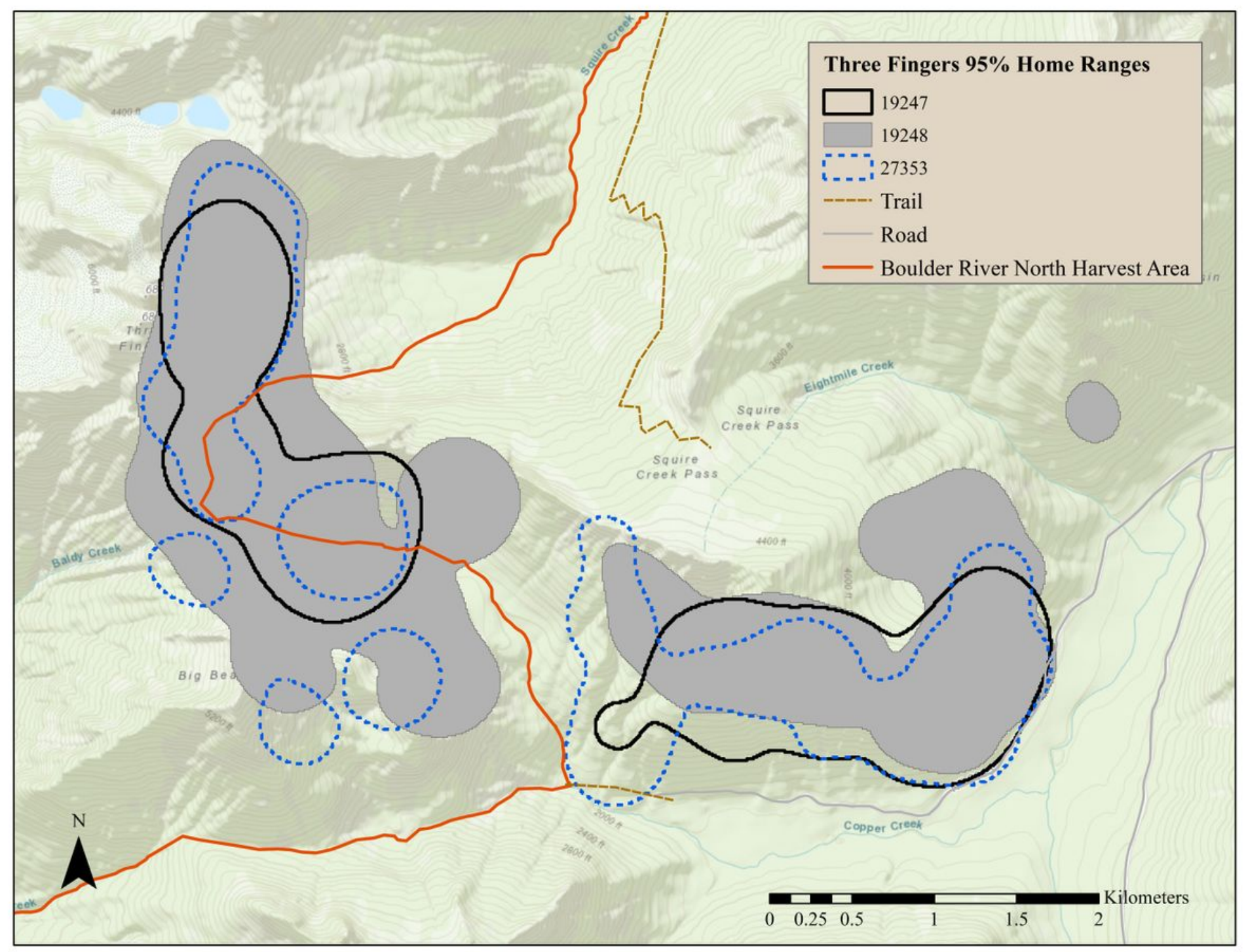

Figure 6

Home range (95\%) distributions for individual mountain goats on Three Fingers Mountain in the Boulder River Wilderness, Washington State, USA (August 2016-October 2019). Note: The designations employed and the presentation of the material on this map do not imply the expression of any opinion whatsoever on the part of Research Square concerning the legal status of any country, territory, city or area or of its authorities, or concerning the delimitation of its frontiers or boundaries. This map has been provided by the authors. 


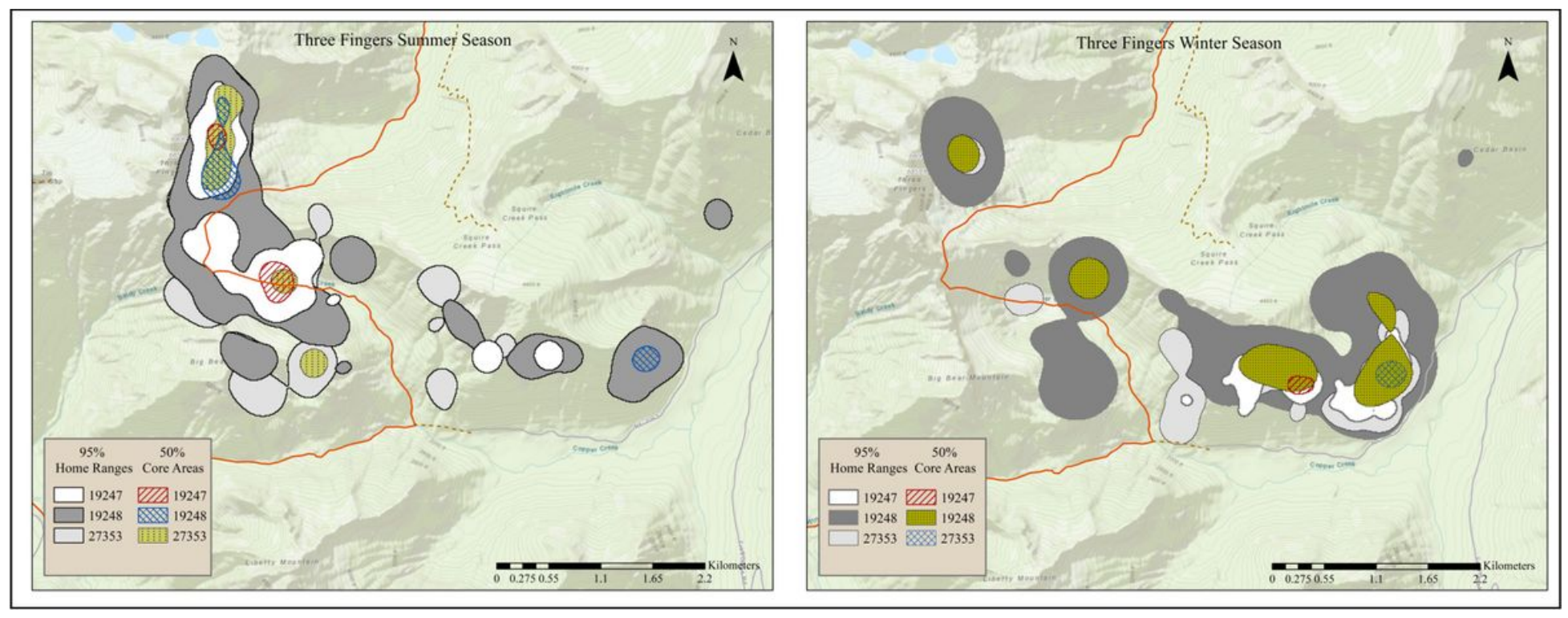

\section{Figure 7}

Seasonal home Range (95\%) and core use (50\%) areas for individual mountain goats on Three Fingers Mountain in the Boulder River Wilderness, Washington State, USA (August 2016-October 2019). Note: The designations employed and the presentation of the material on this map do not imply the expression of any opinion whatsoever on the part of Research Square concerning the legal status of any country, territory, city or area or of its authorities, or concerning the delimitation of its frontiers or boundaries. This map has been provided by the authors. 


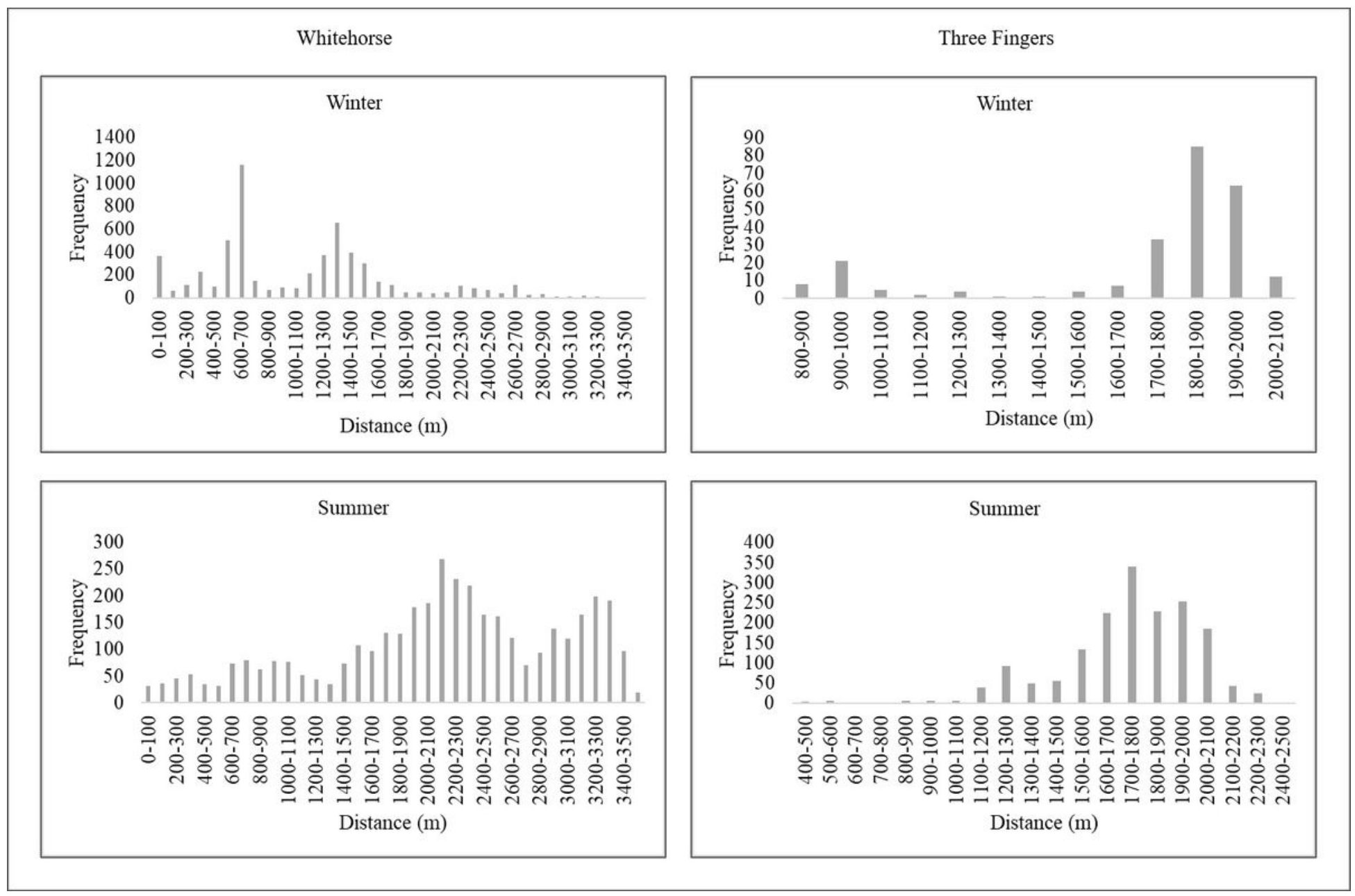

Figure 8

Seasonal frequency distributions of mountain goat locational fix distances $(\mathrm{m})$ on Whitehorse and Three Fingers Mountains to roads and trails in the Boulder River Wilderness, Washington State, USA (August 2016-October 2019). 